\title{
Commercial Multiplication of Gerbera (Gerbera jamesonii Bolus ex. Hooker F.) from Young Capitulum Explants
}

\author{
R. Rashmi ${ }^{*}$, C. Aswath ${ }^{2 *}$, M.V. Dhananjaya ${ }^{2}$ and Satish R. Patil ${ }^{3}$ \\ ${ }^{1}$ College of Horticulture (UHS), Bagalkot, India \\ ${ }^{2}$ Division of Floriculture and Medicinal Crops, ICAR-IIHR, Bengaluru, India \\ ${ }^{3}$ Department of FLA, Kittur Rani Chennamma College of Horticulture, Arabhavi (UHS, \\ Bagalkot), India
}

*Corresponding author

\section{Keywords}

Gerbera,

Micropropagation,

Capitulum, Growth hormones

Article Info

Accepted:

18 October 2018

Available Online:

10 November 2018

\section{A B S T R A C T}

An efficient protocol was developed for commercial multiplication of gerbera using young capitulum as explant across different varieties of gerbera. Media for culture establishment, shoot regeneration, multiplication were standardized. Mercuric chloride treatment $(0.1 \%)$ for 2 minutes was found to be the best surface sterilant for capitulum explants resulting in the minimum per cent contaminated growing cultures (17.27\%). For regeneration MS medium supplemented with $3 \mathrm{mg} / \mathrm{l} \mathrm{BAP}+0.3 \mathrm{mg} / \mathrm{l}$ NAA was found good. The capitulum of six gerbera varieties viz., Arka Krishika, Arka Nesara, Arka Ashwa, Basics, Morelia and Stanza were utilized. Regeneration from capitulum explants was achieved through direct organogenesis and cultures regenerated were multiplied up to five subculture cycles. The variety Arka Ashwa recorded the highest shoot regeneration percentage (70.0\%) followed by Arka Nesara (51.25\%). The number of segments regenerated was high in the Arka Ashwa (28.00) followed by Arka Nesara (20.50) and stanza (20.25). By repeated subculturing of the capitulum explant a high frequency of shoot multiplication was established in MS medium supplemented with $3 \mathrm{mg} / \mathrm{l} \mathrm{BAP}+0.3 \mathrm{mg} / \mathrm{l}$ NAA Arka Nesara recorded highest proliferation (2.3) rate in the $1^{\text {st }}$ subculture followed by Arka Ashwa (2.28). Shoot multiplication was found very low in variety Morelia (1.2). Same trend was observed from $2^{\text {nd }}$ subculture to $5^{\text {th }}$ subculture. The described protocol seems to be technologically suitable for clonal multiplication of gerbera on a large scale, encompassing high genetic and quality propagation material. Within the short span a well acclimatized plants were obtained from a single initial capitulum explant, clearly revealing the potentiality of such technological strategy to overcome the lack of true-to-type propagation material.

\section{Introduction}

Gerbera jamesonii is an ornamental, herbaceous, perennial plant of Asteraceae originated from South Africa. Gerbera is considered as one of the nature's beautiful creations because of having excellent flowers of exquisite shape, size and bewitching colour. It is popularly known as 'Transvaal Daisy, Barberton Daisy or African daisy (Bailey, 1963; Dole and Welkins, 1999). The major importance of gerbera in the international 
flower market is as cut flower and it suits a wide range of floral arrangements.

The growth of floriculture industry has taken long strides world-wide especially in the developing countries as a result of outsourcing which is due to low cost of maintenance including low labor cost (Jain 2006). For that reason gerbera has gained popularity in the past few years in many countries of the world and it is in great demand in the floral industry as cut flower as well as potted plant due to its beauty, color, long vase life (Kanwar and Kumar 2008). The market value of gerbera is high in the US, Japan, Germany and in the UK. In Europe, the Netherlands and in Asia Indonesia as well as Malaysia are the dominant gerbera suppliers world-wide. In India, Commercial production of gerbera is centered around Pune and Bengaluru, Parts of Sikkim, Nagaland, Meghalaya and Uttarkhand, from where flowers are being sent to local and international market. In light of global demand, gerbera could be a major source of foreign exchange. In this aspect, mass commercial production of gerbera could be acted as a new dimension. However, using conventional propagation system it is simply not possible to fulfill the demand of the export market. The non-availability of good quality planting material of commercially important variety is a major constraint for widespread and commercial cultivation in India.

Its commercial propagation by both sexual and asexual methods. Seed propagation however is not always satisfactory, since impurity of strain produces a great deal of variation (Sachiva, 1975). Most of the commercially grown cultivars are propagated through vegetative means by division of suckers or clumps, to maintain uniformity and genetic purity (Peper et al., 1971). It is extremely heterozygous. Multiplication through vegetative propagation by divisions is too slow to be commercially viable and production of large number uniform propagules (Aswath and Choudary, 2001) Thus in vitro propagation of gerbera can be solution for commercial multiplication of plants. Micro propagation is free of seasonal bonds and enables large scale multiplication of selected plants. However this method have several advantages such as plants are uniform, free from disease, ease the exchange of germplasm and good quality planting material. Further this technique is basis for application of different genetic improvement tools, viz., in vitro selection and genetic transformation.

The in vitro response in gerbera varies cultivar, types explants used, growth hormones and composition of media. From the literature it is evident that gerbera are highly amenable to in vitro studies, as various explants such as shoot tip, leaf, petiole, and other parts of the plant were found to favorably respond to different culture media with different types and concentrations of growth hormones. Over the years, many researchers have studied microprogation of gerbera and different methods of in vitro multiplication and explants including callus induction and regeneration from leaves (Prasanth and Sekar, 2004, Chen et al., 2006), shoot regeneration from petiole (Kumar et al., 2004, Chen et al., 2006), direct shoot induction from shoot tips (Parthasarathy and Nagaraju, 1999; Aswath and Choudhary, 2004; Thakur et al., 2004 and Aswath and Nazneen, 2004), Capitulum (Mohammed and Ozzambak, 2007; Modh et al.,2002; Zheng et al., 2002; Mandal and Datta, 2002; Ray et al., 2005 and Shylaja et al., 2014) and Floral receptacle (Wang and Xiang, 2001 and Nhut et al., $2006 \&$ 2007). Shoot tip culture is the most commonly followed in vitro method for commercial multiplication. This method allows for obtaining large amount of healthy and homogenous plants. However shoot tip is highly prone to contamination since it has high pubic hair. The advantage of capitulum 
over shoot tip is easier and sterile isolation and it is also a non-destructive method, immature buds are used and no shoots are lost fron the plant (Pierik et al., 1982). Hence the present investigation was undertaken to develop a successful, highly efficient and economically viable protocol for rapid clonal propagation from young capitulum explant across different varieties of gerbera.

\section{Materials and Methods}

\section{Plant material and explant preparation}

The gerbera cultivars Arka Ashwa, Arka Krishka, Arka Nesara, Basics, Morelia and Stanza were grown under polyhouse conditions at ICAR-Indian Institute of Horticultural Research, Bengaluru. All the recommended cultural practices were followed with regular spraying of plant protection chemicals to avoid pests and diseases. The tissue culture experiments were conducted and repeated during the year 2016-18.The unopened flower buds with basal diameter $1.0-1.5 \mathrm{~cm}$ (Fig. 2) were collected from polyhouse. Young capitula were collected from plants were washed thoroughly in running tap water followed by distilled water and buds are thoroughly washed in tween-20 for ten minutes. Explants were rinsed several times in sterile distilled water and pretreated with with $0.1 \%$ Bavistin for 15 min (Fig. 2).

For surface sterilization of explants surface sterilants viz., Mercuric $\left(\mathrm{HgCl}_{2}\right)$ chloride and Hydrogen peroxide $\left(\mathrm{H}_{2} \mathrm{O}_{2}\right)$ treatments were standardized. The excised explants were treated with $\mathrm{HgCl} 2(0.1 \%, 0.2 \%$ and $0.3 \%)$ and $\mathrm{H}_{2} \mathrm{O}_{2}(0.05 \%, 0.1 \%, 0.15$ and $0.20 \%)$ for 2 minutes. The explants were stirred in the sterilizing solution during the treatment. The explants were then thoroughly washed 3-4 times with sterile distilled water before placing them on MS medium.Before inoculation the outer bracts and sepals were removed from flower bud and it was made into four to six longitudinal segments.

\section{Culture establishment}

For initiation of multiplication, the 15 young capitulum per treatment of Arka Ashwa were made in to 60 segments and inoculated in to the on basal MS medium (Murashige and Skoog, 1962) supplemented with different concentrations of BAP $(1,2, \& 3 \mathrm{mg} / \mathrm{l})$ and BAP $1 \mathrm{mg} / \mathrm{l}$ + NAA $0.1 \mathrm{mg} / \mathrm{l}$, BAP $2 \mathrm{mg} / \mathrm{l}+$ NAA $0.2 \mathrm{mg} / \mathrm{l}$ and BAP $3 \mathrm{mg} / \mathrm{l}+\mathrm{NAA} 0.3$ $\mathrm{mg} / \mathrm{l}$, Medium without hormone serve as control. Number of segments regenerated, per cent regeneration, contamination and Necrosis was recorded. The $\mathrm{pH}$ of the medium was adjusted to 5.6-5.8 with drop wise addition of I $\mathrm{N} \mathrm{NaOH}$ or $1 \mathrm{~N} \mathrm{HCl}$ using a digital $\mathrm{pH}$ meter before the addition of $0.8 \%(\mathrm{~W} / \mathrm{V})$ agar agar. Molten medium $(50 \mathrm{ml})$ was dispensed into culture bottles and autoclaved at $121^{\circ} \mathrm{c}$ and $15 \mathrm{lbs}$ for 15 minutes. Segments of surface disinfected explant were implanted on the culture media. All the cultures were maintained under continuous darkness at $25^{\circ} \mathrm{c} \pm 2^{\circ} \mathrm{c}$ for 5 weeks, then transferred under continuous fluorescent light (2100lux) $25^{\circ} \mathrm{c} \pm 2^{\circ} \mathrm{c}$ for 3 weeks.

\section{Shoot regeneration across different varieties}

Three hybrid selections viz., Arka Ashwa, Arka Nesara and Arka Krishika released from ICAR-IIHR Bengaluru, developed through hybridization (half-sib) between IIHR-3 and mixed pollen of 10 varieties followed by selection and three varieties Basics, Morelia and stanza procured from private company were used for the shoot regenartion. Details of flower characters are provided in Table 1. Source plants were maintained in net house of ICAR-IIHR, Bengaluru. The varieties with different flower colours were included in Plate 1. The best treatment from previous 
experiment was used across 6 varieties for shoot regeneration and observations are recorded on numbers of segments regenerated, shoot regeneration (\%) and number of shoots proliferated from $1-5^{\text {th }}$ subculture.

The capitulum is the unopened consists of ray, trans and disc florets arranged on a receptacle. Capitulum is one of the explant used for the initiation and multiplication (Fig. 3-5). The size and the development stage is one of the important factors influencing the regeneration ability in addition to growth hormones. This explant can be safely used as the plants produced are uniform and true to type

\section{Acclimatization and transfer of plantlets to soil}

Plantlets with well-developed roots were removed from culture medium devoid of agar agar. After gentle washing with sterile double distilled water, well developed plants were transferred to cocopeat and then to the pots with potting mixture of sterile sand and cocopeat $(1: 3 \mathrm{v} / \mathrm{v})$. Plantlets were maintained in glass house and after 4 weeks these plantlets were transferred into polythene covers containing potting medium. Small pin holes were made at the bottom of the bottom of the cover and top was closed to maintain humidity.

The data on various biometrical parameters recorded during the period of study was subjected to statistical analysis as per the procedure given by Panse and Sukhatme (1967). The data was analyzed employing completely randomized design with equal number (3) of replications. The results have been presented and discussed at the probability level of one per cent.

\section{Results and Discussion}

The morphological potential in gerbera varied with the developmental stage of explants.
Type of explant, stage, growth, biochemical composition, coupled with the presence of phytohormones, their ratio and level etc. decide the in vitro behaviour of explants. Quicker and higher in vitro shoot production from immature floral buds than that of fully developed inflorescences in gerbera. In immature capitulum, initially no significant change in the morphology of the floral bud was observed except loosening of florets and drying of outer involucral bracts. Subsequently, growth of florets was seen in the form of swelling and greening of the florets. Later, shoot development occurred directly from these florets. This might be due to the formation of meristematic tissues in segment of immature flower heads (Mandal et al., 2002). In few explants, shoot emergence was seen on the completely dried explant from the base of the receptacles.

The age of flower buds (judged by size) was found to be a crucial factor for culture establishment and shoot regeneration, the optimum being unopened flower buds with basal diameter of 1.0-1.2 cm (Fig. 1), the bigger and smaller buds were not giving response with respect to culture establishment and shoot regeneration. Genotypic difference was also observed in all stages of in vitro propagation. There are some previous reports on using of flower bud as explants for shoot regeneration in gerbera (Pierik et al., 1975, Laliberte et al., 1985, Aswath and Choudhary 2002, Tyagi and Kothari 2004, Ray et al., 2005, Kumar and Kanwar 2006 and 2007, Nhut et al., 2007 and Shylaja et al., 2014).

In the present study, Treatment of capitulum with different concentrations of $\mathrm{HgCl}_{2}$ and $\mathrm{H}_{2} \mathrm{O}_{2}$ (Table 2) reduced the microbial contamination significantly and improved the survival percentage as compared to $T_{0}$ (Control). Among the different treatments, $\mathrm{T}_{3}$ recorded with minimum contamination (17.27) followed by $\mathrm{T}_{6}(20.63 \%)$ over control (98.11\%). Highest explants survival (47.33\%) 
and minimum necrosis $(6.67 \%)$ was observed in $\mathrm{T}_{1}$ treatments. Maximum necrosis $(57.43 \%)$ of explants was found in $\mathrm{T}_{3}\left(\mathrm{HgCl}_{2} @ 0.30 \%\right)$ as compare to $\mathrm{T}_{1}(6.67 \%)$ and $\mathrm{T}_{2}(12.17 \%)$ treatments, that might be due to bleaching of tissues at higher concentration of $\mathrm{HgCl}_{2}$ and $\mathrm{H}_{2} \mathrm{O}_{2}$.

Among two surface sterilants tested $\left(\mathrm{HgCl}_{2}\right.$ and $\mathrm{H}_{2} \mathrm{O}_{2}$.) treatments, for capitulum $\mathrm{T}_{1}(0.1 \%$ $\mathrm{HgCl}_{2}$ ) found suitable to control maximum contamination $(98.11 \%)$, maximum explants survival (47.33\%) as compared to $\mathrm{T}_{0}$ (control) and $\mathrm{H}_{2} \mathrm{O}_{2}$ treatments These results are similar to the findings of Warar et al., (2008) who obtained best results by treating capitulum explants with $\mathrm{HgCl}_{2}$ for 5 minutes. This is also in close conformity with the findings of Modh et al., (2002) who surface sterilized young capitulum explants taken from gerbera $\mathrm{cv}$. 'Atella' and obtained maximum uncontaminated growing cultures when explants were treated with mercuric chloride (0.1\%) for 5 minutes and Altaf et al., (2009) surface sterilized Gerbera seeds with $0.1 \%$ $\mathrm{HgCl} 2$ solution for two minutes and were thoroughly washed with sterile water. Srivastava and Sharma (2005) firstly treated leaf segments and petioles with carbendazim $(0.2 \%)$ for 30 minutes and surface sterilized with mercuric chloride $(0.1 \%)$ for 10 minutes followed by 3-4 washing with sterilized distilled water. Similarly Aswath and Choudhary (2001) surface sterilized gerbera shoot tips in labonene for a few seconds plus $0.1 \%(\mathrm{v} / \mathrm{v})$ mercuric chloride for 3 minutes and thoroughly washed 3-4 times in sterile distilled water. Eventhough $\mathrm{H}_{2} \mathrm{O}_{2}$ is also a good it did not perform well with capitulum explants. From the present investigation $0.1 \%$ $\mathrm{HgCl}_{2}$ for $2 \mathrm{~min}$ found to good for surface sterilization of Capitulum explants. Hence for further experiments treatment $0.1 \% \mathrm{HgCl}_{2}$ was used as surface sterilants.

Surface sterilization of explants and culture establishment are the most critical factors for in vitro morphogenesis and the success depends largely upon several factors like correct choice of explants, physiological state of the explants, adoption of the most suitable surface sterilization procedure and selection of appropriate growth regulator combinations in a culture medium besides maintaining the requisite temperature and light conditions in the culture room. Each stage in in vitro culture of plants also needs suitability responses of explant, culture medium and culture condition (Winarto and Yufdy, 2017).Flower bud was appeared to be a good responsive explant towards shoot regeneration. The induction media had significant effect on initial culture establishment from capitulum explant.

Regeneration was observed only in the two treatments (Table 3), however, maximum number of segments (45.33) and maximum regeneration $(75.55 \%)$ were regenerated in the MS medium supplemented with BAP $3 \mathrm{mg} / \mathrm{l}+$ NAA $0.3 \mathrm{mg} / \mathrm{l}$. The explants and growth regulator combinations have also exhibited a marked effect on in vitro culture establishment.

The culture establishment for capitulum explants on MS medium supplemented with 3 $\mathrm{mg} / \mathrm{l} \mathrm{BAP}+0.3 \mathrm{mg} / \mathrm{l} \mathrm{NAA}$ was found to be the best. The results are similar to findings of various researchers Akter et al., (2012), flower bud and flower stalk explants were suitable and superior for callus induction and subsequent regeneration of in vitro shoots, when cultured in MS supplemented with 5.0 $\mathrm{mg} / \mathrm{l} \mathrm{BAP}$ and $1.0 \mathrm{mg} / \mathrm{l}$ NAA. However, highest numbers of multiple shoots were obtained when the flower bud derived callus was subcultured on MS supplemented with 2.0 $\mathrm{mg} / \mathrm{l}$ BAP. Direct shoot regeneration were observed in MS medium containing $3.0 \mathrm{mg} / \mathrm{l}$ BAP and $0.1 \mathrm{mg} / 1$ NAA. Warar et al., (2008) reported the best culture establishment of capitulum explants of gerbera cv. 'Sciella' in 60.73 days on MS medium containing $3 \mathrm{mg} / \mathrm{l}$ $\mathrm{BAP}+0.5 \mathrm{mg} / \mathrm{l} \mathrm{IAA}$. However, Pierik et al., 
(1975) obtained shoots on excised capitulum explants after 8 weeks. Laliberte et al., (1985) obtained shoots on capitulum explants of gerbera cv. 'Pastourelle' on a medium containing $2 \mathrm{mg} / \mathrm{l} \mathrm{BA}$ and $0.1 \mathrm{mg} / \mathrm{l} \mathrm{IAA}$ after a culture period of 8 weeks. However, they also obtained maximum shoots on same explants in gerbera cv. 'Mardi Gras' on a medium containing $1 \mathrm{mg} / \mathrm{l} \mathrm{BA}$ and $0.1 \mathrm{mg} / \mathrm{l} \mathrm{IAA}$ after 8 weeks. Similarly, Modh et al., (2002) obtained maximum shoot proliferation rate of gerbera cv. 'Atella' at $3 \mathrm{mg} / \mathrm{l} \mathrm{BAP}+0.1 \mathrm{mg} / \mathrm{l}$ IAA after 4 weeks of incubation period. Hence from the present investigation BAP $3 \mathrm{mg} / \mathrm{l}$ and NAA $0.3 \mathrm{mg} / \mathrm{l}$ found to be the best shoot regeneration so the same medium was used for shoot regeneration across different varieties of gerbera.

The unopened 15 days capitulum of all the varieties were collected from source plants were made into vertical segments and they were inoculated to best culture establishment medium in the previous experiment i.e., MS medium supplemented with $3 \mathrm{mg} / \mathrm{l}$ BAP and $0.3 \mathrm{mg} / \mathrm{l}$ NAA. Shoot regeneration was observed in the culture establishment medium itself. Shoot morphogenesis and response are presented in Table 4. Shoot regeneration was recorded four weeks after inoculation. The variety Arka Ashwa recorded the highest shoot regeneration percentage $(70.0 \%)$ followed by Arka Nesara (51.25\%). The number of segments regenerated was high in the Arka Ashwa (28.00) followed by Arka Nesara (20.50) and stanza (20.25).

The number of adventitious shoots produced in vitro also depends on the flower bud size and age. In the present study, shoot regeneration percentage was 70.0. Out of 40 flower bud inoculated only in 28 segments shoot regeneration was observed. The growth response is also said to be cultivar specific (Schiva et al., 1982; Pierik et al., 1982 and Harel et al., 1993). Explants of cv. Marleen formed 14.8 and 13.2 shoots on the initiation medium containing BA and kinetin respectively; those of $\mathrm{cv}$. Victoria formed 11.8 and 2.2 shoots, respectively (Hempel et al., 1985). Deepaja (1999) also reported that, every genotype has a specific range of optimum growth regulator concentration. The same trend also observed in the present investigation. Schum and Busold (1985) also reported quicker and higher in vitro shoot production from immature floral buds than that of fully developed inflorescences in gerbera. In present study also, similar results were found. Son et al., (2011) also used flower buds of three varieties of gerbera as explants for culture establishment. Results are similar to present study. Bhatia et al (2012) also found best establishment of immature capitulum explants was obtained on modified MS medium supplemented with $10 \mathrm{mg} / \mathrm{l} \mathrm{BAP}$ and $1 \mathrm{mg} / \mathrm{l}$ IAA. Kadu (2013) also found highest shoot regeneration percentage $(91.66 \%)$ in MS medium supplemented with $2.0 \mathrm{mg} / \mathrm{l} \mathrm{BAP}$ and $0.5 \mathrm{mg} / \mathrm{l}$ NAA from flower bud explants. Similar results were also found in the present study with low concentration BAP and NAA. Similar results also found by Rahman et al., (2014). Shylaja et al., (2014) developed a highly efficient micropropagation protocol for multiplication of gerbera with unopened flower bud as explants. For culture establishment, MS medium supplemented with $3.0 \mathrm{mg} / \mathrm{l} \mathrm{BAP}$ and NAA $0.1 \mathrm{mg} / \mathrm{l}$ was found highest shoot regeneration percentage $(95.83 \%)$ and high number of shoot regeneration (42.33) in variety Dubai. Genotype differences were observed in all stages of in vitro propagation. Same results were obtained in the present study and with respect to variety Arka Ashwa, shoot regeneration percentage $(70.0 \%)$.

In immature capitulum, initially no significant change in the morphology of the floral bud was observed except loosening of florets and drying of outer involucral bracts. 
Table.1 Flower characters of selected gerbera varieties

\begin{tabular}{|l|c|c|c|c|c|c|}
\hline Characters & Arka Ashwa & Arka Nesara & Arka Krishika & Basics & Morelia & Stanza \\
\hline Type of flower & Semi double & Semi double & Semi double & Semi double & Semi double & Semi double \\
\hline Flower colour & $\begin{array}{l}\text { Red purple } \\
\text { group 68 D }\end{array}$ & $\begin{array}{c}\text { Red Group } \\
50 \mathrm{~A}\end{array}$ & $\begin{array}{c}\text { Yellow group } \\
\text { 22B }\end{array}$ & $\begin{array}{c}\text { Red-purple } \\
\text { group 60-D }\end{array}$ & $\begin{array}{c}\text { Red purple } \\
\text { group 58-B }\end{array}$ & $\begin{array}{c}\text { Red group 45 } \\
\text { Ad }\end{array}$ \\
\hline $\begin{array}{l}\text { Stalk length } \\
\text { (cm) }\end{array}$ & 61.06 & 38.85 & 49.90 & 67.54 & 64.67 & 63.54 \\
\hline $\begin{array}{l}\text { Flower } \\
\text { Diameter(cm) }\end{array}$ & 10.85 & 8.92 & 8.00 & 10.40 & $6-12$ & 10.82 \\
\hline $\begin{array}{l}\text { Flower } \\
\text { yield/plant/year }\end{array}$ & 39.50 & 36.80 & 42.00 & 32.00 & 31.50 & 34.90 \\
\hline
\end{tabular}

Table.2 Effect of surface sterilants on contamination and necrosis

\begin{tabular}{|c|l|c|c|c|}
\hline Treatments & \multicolumn{1}{|c|}{$\begin{array}{c}\text { Surface } \\
\text { sterilants }\end{array}$} & $\begin{array}{c}\text { Contamination } \\
(\boldsymbol{\%})\end{array}$ & $\begin{array}{c}\text { Necrosis } \\
(\mathbf{\%})\end{array}$ & $\begin{array}{c}\text { Survival } \\
(\boldsymbol{\%})\end{array}$ \\
\hline $\mathbf{T}_{\mathbf{0}}$ & Control & 98.11 & $0.00(1.00)$ & 1.89 \\
\hline $\mathbf{T}_{\mathbf{1}}$ & $\mathbf{0 . 1} \% \mathbf{H g C l}$ & 46.00 & $6.67(2.75)$ & 47.33 \\
\hline $\mathbf{T}_{\mathbf{2}}$ & $\mathbf{0 . 2} \% \mathbf{H g C l}_{\mathbf{2}}$ & 42.66 & $12.17(3.62)$ & 45.17 \\
\hline $\mathbf{T}_{\mathbf{3}}$ & $\mathbf{0 . 3} \% \mathbf{H g C l}_{\mathbf{2}}$ & 17.27 & $57.43(7.55)$ & 26.72 \\
\hline $\mathbf{T}_{\mathbf{4}}$ & $\mathbf{0 . 1 0 \%} \underline{\mathbf{H}}_{2} \underline{\mathbf{O}}_{2}$ & 63.22 & $13.00(3.74)$ & 32.11 \\
\hline $\mathbf{T}_{\mathbf{5}}$ & $\mathbf{0 . 1 5 \%} \underline{\mathbf{H}}_{2} \underline{\mathbf{O}}_{\mathbf{2}}$ & 24.38 & $30.95(5.65)$ & 44.66 \\
\hline $\mathbf{T}_{\mathbf{6}}$ & $\mathbf{0 . 2 0} \% \mathbf{H}_{\mathbf{2}} \mathbf{O}_{\mathbf{2}}$ & 20.63 & $54.13(7.42)$ & 25.23 \\
\hline $\mathbf{S . E m} \pm$ & & $\mathbf{0 . 7 1 9}$ & $\mathbf{0 . 3 3}$ & $\mathbf{3 . 3 8}$ \\
\hline $\mathbf{C D} @ \mathbf{1 \%}$ & & $\mathbf{2 . 1 4}$ & $\mathbf{0 . 0 7 7}$ & $\mathbf{1 4 . 2 5}$ \\
\hline
\end{tabular}

* Figures in parentheses are square root transformed values

* Number of capitulum inoculated per treatment -10

* Number of capitulum segments inoculated per treatment- 40

Table.3 Effect of different concentrations of BAP and NAA for shoot regeneration of gerbera capitulum Cv. Arka Ashwa

\begin{tabular}{|l|l|c|c|}
\hline & Hormones (mg/l) & No. of segments regenerated & Regeneration (\%) \\
\hline $\mathbf{T}_{1}$ & Control & $0.00(1.00)$ & $0.00(1.00)$ \\
\hline $\mathbf{T}_{\mathbf{2}}$ & MS + BAP 1 & $0.00(1.00)$ & $0.00(1.00)$ \\
\hline $\mathbf{T}_{\mathbf{3}}$ & MS + BAP 2 & $0.00(1.00)$ & $0.00(1.00)$ \\
\hline $\mathbf{T}_{\mathbf{4}}$ & MS + BAP 3 & $0.00(1.00)$ & $0.00(1.00)$ \\
\hline $\mathbf{T}_{\mathbf{5}}$ & MS + BAP 1 NAA 0.1 & $0.00(1.00)$ & $0.00(1.00)$ \\
\hline $\mathbf{T}_{\mathbf{6}}$ & MS + BAP 2 + NAA 0.2 & $17.67(4.31)$ & $29.44(5.51)$ \\
\hline $\mathbf{T}_{7}$ & MS + BAP 3 + NAA 0.3 & $45.33(6.80)$ & $75.55(8.74)$ \\
\hline S.Em \pm & $\mathbf{0 . 1 9}$ & $\mathbf{0 . 0 8 2}$ \\
\hline CD $@$ 1\% & $\mathbf{0 . 2 6 6}$ & $\mathbf{0 . 2 5}$ \\
\hline
\end{tabular}

* Figures in parentheses are square root transformed values

* Number of capitulum inoculated per treatment - 15

* Number of capitulum segments inoculated per treatment- 60 
Table.4 Response of different gerbera varieties for shoot regeneration from capitulum explants

\begin{tabular}{|l|l|c|c|}
\hline \multicolumn{1}{|c|}{ Varieties } & $\begin{array}{c}\text { No. of segments } \\
\text { regenerated }\end{array}$ & $\begin{array}{c}\text { Shoot } \\
\text { regeneration (\%) }\end{array}$ \\
\hline $\mathbf{T}_{\mathbf{1}}$ & Arka Krishika & 16.50 & 41.25 \\
\hline $\mathbf{T}_{\mathbf{2}}$ & Arka Nesara & 20.50 & 51.25 \\
\hline $\mathbf{T}_{\mathbf{3}}$ & Arka Ashwa & 28.00 & 70.00 \\
\hline $\mathbf{T}_{\mathbf{4}}$ & Morelia & 12.25 & 30.63 \\
\hline $\mathbf{T}_{\mathbf{5}}$ & Basics & 10.50 & 26.25 \\
\hline $\mathbf{T}_{\mathbf{6}}$ & Stanza & 20.25 & 50.63 \\
\hline $\mathbf{S . E m} \pm$ & $\mathbf{0 . 6 7}$ & $\mathbf{1 . 6 8}$ \\
\hline $\mathbf{C D}$ @ $\mathbf{1 \%}$ & $\mathbf{2 . 7 3}$ & $\mathbf{6 . 8 3}$ \\
\hline
\end{tabular}

*Number of capitulum inoculated per treatment - 10

*Number of capitulum segments inoculated per treatment- 40

Table.5 Response of different gerbera varieties for shoot proliferation from single shoot tip explant

\begin{tabular}{|l|c|c|c|c|c|}
\hline \multicolumn{1}{|c|}{ Varieties } & $\begin{array}{c}\mathbf{1}^{\text {st }} \\
\text { Subculture }\end{array}$ & $\begin{array}{c}\mathbf{2}^{\text {nd }} \\
\text { Sub culture }\end{array}$ & $\begin{array}{c}\mathbf{3}^{\text {rd }} \\
\text { Sub culture }\end{array}$ & $\begin{array}{c}\mathbf{4}^{\text {th }} \\
\text { Sub culture }\end{array}$ & $\begin{array}{c}\mathbf{5}^{\text {th }} \\
\text { Sub culture }\end{array}$ \\
\hline $\begin{array}{l}\text { Arka } \\
\text { Krishika }\end{array}$ & 1.3 & 1.69 & 2.19 & 2.86 & 3.72 \\
\hline Arka Nesara & 2.3 & 5.29 & 12.16 & 27.98 & 64.36 \\
\hline Arka Ashwa & 2.28 & 5.2 & 11.85 & 27.02 & 62.62 \\
\hline Morelia & 1.2 & 1.44 & 1.73 & 2.07 & 2.49 \\
\hline Basics & 1.45 & 1.96 & 2.75 & 3.84 & 5.37 \\
\hline Stanza & 1.3 & 1.69 & 2.19 & 2.86 & 3.72 \\
\hline
\end{tabular}

Fig.1 Different lines of gerbera used in the experiment
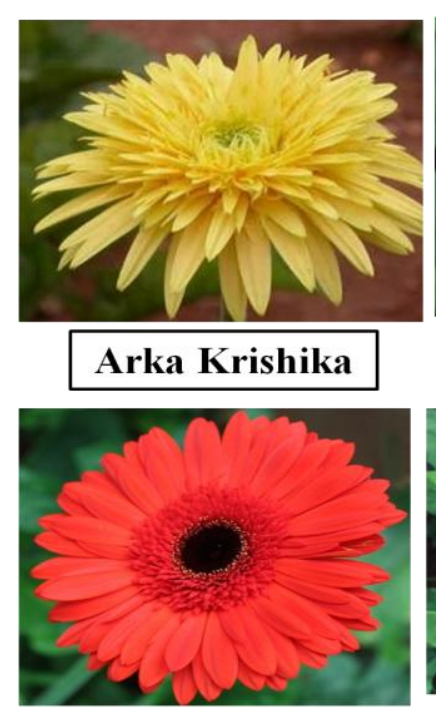

Stanza

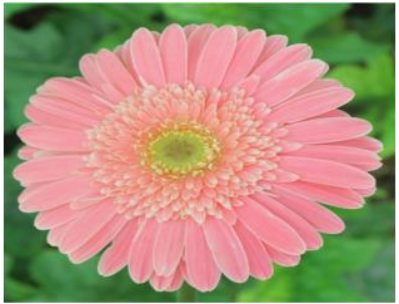

Arka Ashwa

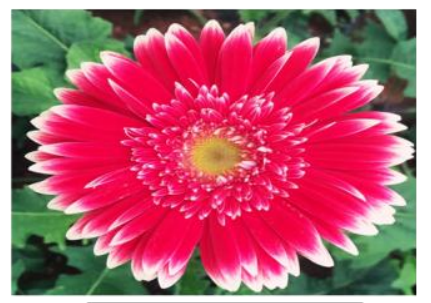

Morelia

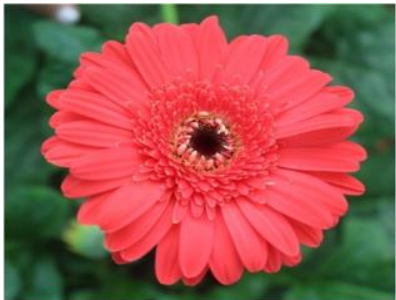

Arka Nesara

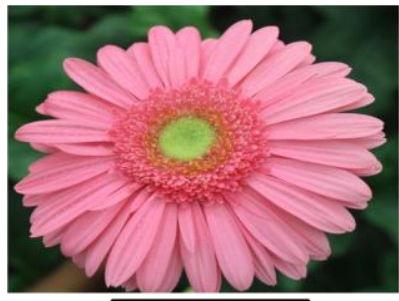

Basics 
Fig.2 Different stages of young capitulum

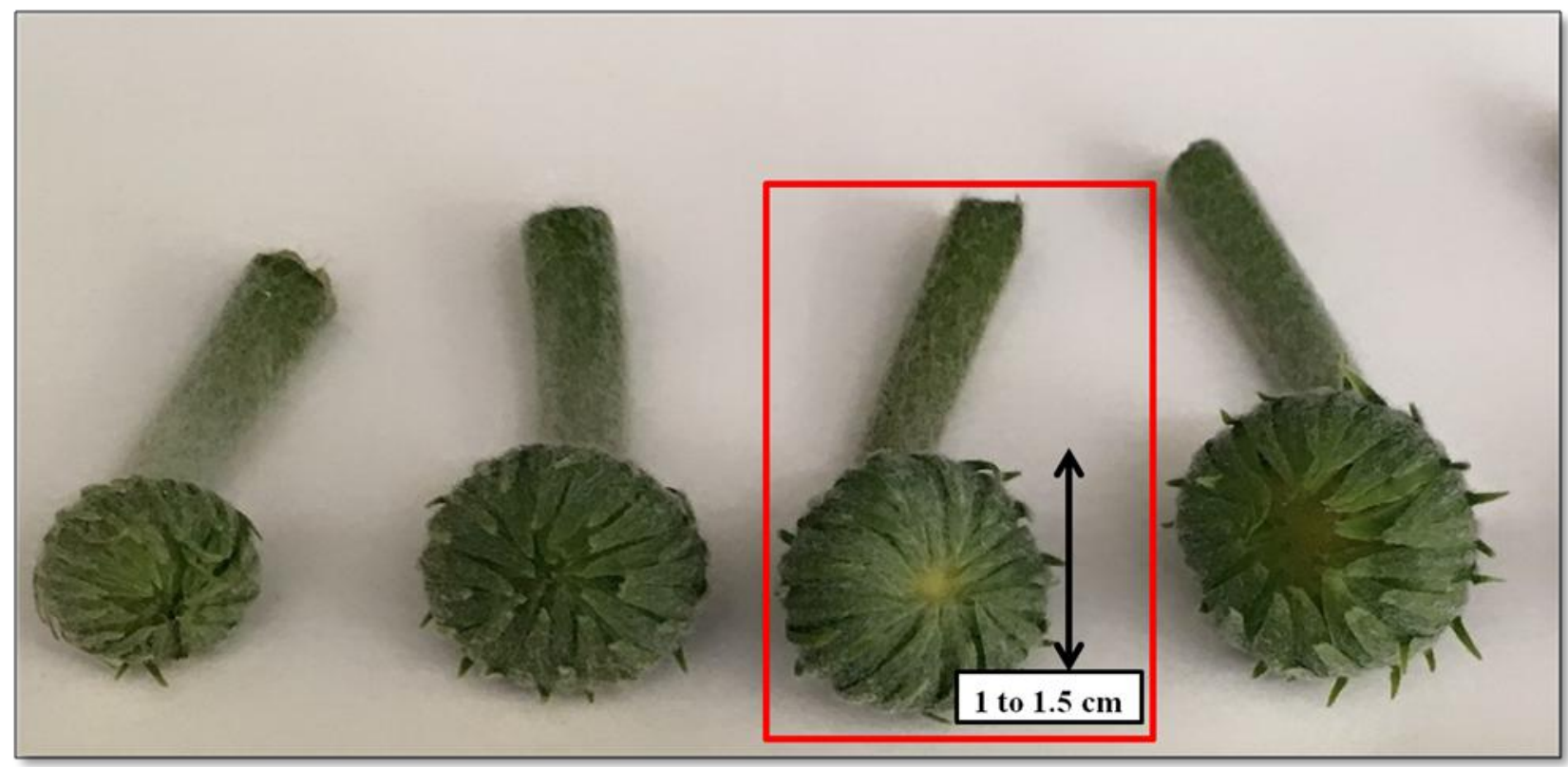

Fig.3 Flow chart for the explant preparation

Young capitulum were collected from plants were washed thoroughly in running tap water followed by distilled water

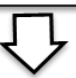

Buds are thoroughly washed with tween 20 for $10 \mathrm{~min}$

Pretreated with $0.1 \%$ Bavistin for $15 \mathrm{~min}$

そ

Explants were rinsed several times with sterile distilled water

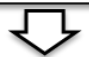

Surface sterilization with $0.1 \%(\mathrm{w} / \mathrm{v}) \mathrm{HgCl}_{2}$ for $3-5 \mathrm{~min}$

ए

Explants were washed thrice in sterile distilled water to remove traces of $\mathrm{HgCl}_{2}$

$\checkmark$

Outer bracts and sepals were removed from capitula and cut into 4-6 longitudinal segments and placed in MS mediun supplemented with NAA-BAP combination 
Fig.4(a-e) a. Flower bud used as explant for shoot regeneration, b. Transverse section of flower bud used as explant for shoot regeneration c, $d$ and e. Induction of Shoots from the flower bud explant and f. Regeneration of multiple shoots from the flower bud explant
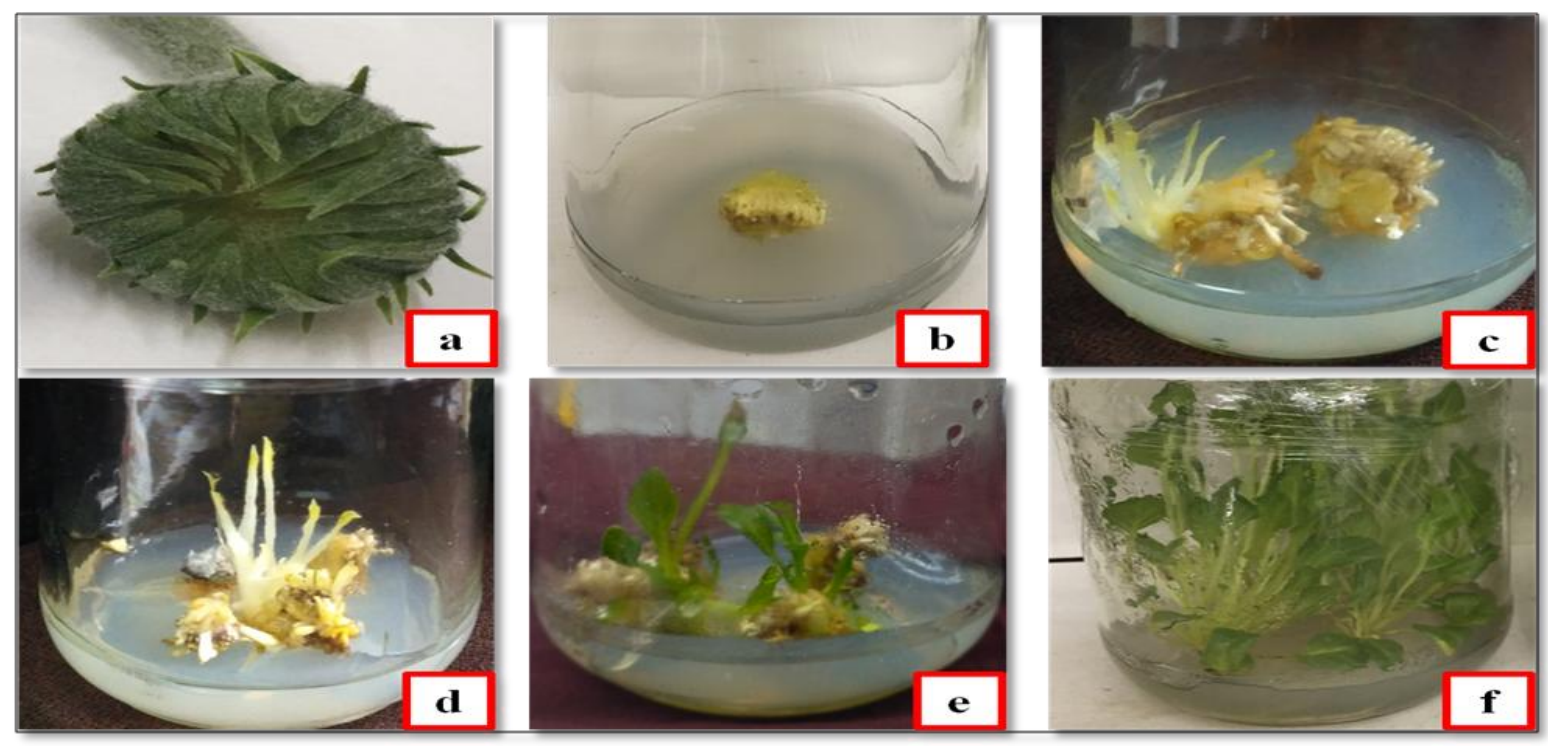

Fig.5 Standardized protocol for commercial multiplication of gerbera by using young capitulum as explants

Standardized protocol for commercial multiplication of gerbera

Explant: Immature Capitulum

Pretreatment: Bavistin $(0.1 \%)$ for $15 \mathrm{~min}$

Multiplication cycle

Surface sterilization: $\mathrm{HgCl}_{2}(0.1 \%)$ for 2

min

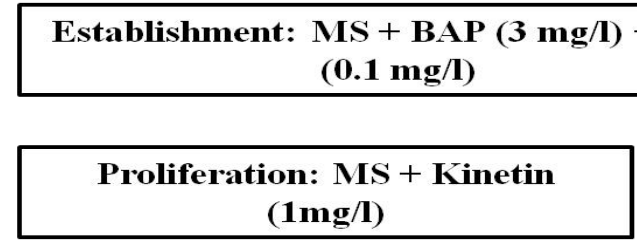

Rooting: MS + IAA (0.1mg/l)

Hardening: Jiffy plugs 3-5weeks

6-9 weelks

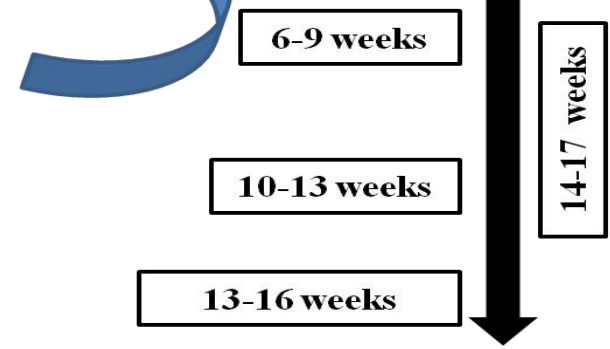

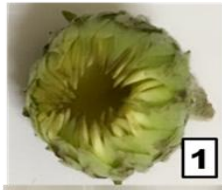

4
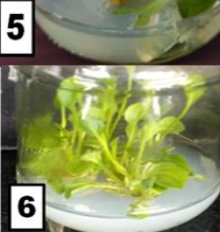
Subsequently, growth of florets was seen in the form of swelling and greening of the florets. Later, shoot development occurred directly from these florets. This might be due to the formation of meristematic tissues in segment of immature flower heads (Mandal et al., 2010).

For shoot proliferation, MS medium supplemented with $3.0 \mathrm{mg} / \mathrm{l}$ BAP and 0.3 mg/l NAA was employed. Number of shoots regenerated was recorded for a period of five subculture cycles. Subculturing was done at one month interval (Table 5). Progressive total of number of shoots regenerated from a single culture showed that the variety Arka Nesara recorded highest proliferation (2.3) rate in the $1^{\text {st }}$ subculture followed by Arka Ashwa (2.28). Shoot multiplication was found very low in variety Morelia (1.2). Same trend was observed from $2^{\text {nd }}$ subculture to $5^{\text {th }}$ subculture.

Maximum number of shoots regenerated from a single culture showed the proliferation rate of 2.3 in number with 64.36 shoots multiplied at $5^{\text {th }}$ sub culture in the variety Arka Nesara followed by 22.28 in number with 62.62 shoots multiplied at $5^{\text {th }}$ sub culture in the variety Arka Ashwa. In vitro shoot regeneration of gerbera is dependent on cultivar and hormonal combination. Growth and morphogenesis in vitro are regulated by the interaction and balance between the growth regulators supplied in the medium and the growth substances produced endogenously by the cultured cells. Various combinations of cytokinins and auxins have been tried to achieve multiple shoot induction in gerbera (Murashige et al., 1974 and Schiva et al., 1982). Apart from the direct effect on cellular mechanisms, many synthetic growth regulators may in fact modify the level of endogenous substances (George and Sherrington, 1984).
Even though several explants like leaves (Son et al., 2011) petioles (Orlikowska et al., 1999), capitulum (Pierik et al., 1975), shoot tips (Murashige et al., 1974 and Aswath et al., 2003) and flower buds (Ray et al., 2005, Son et al., 2011 and Shylaja et al., 2014) were tried for in vitro propagation of gerbera, successful protocols were reported only from shoot tip and flower buds. As compared to shoot tips, the flower bud explants are very good option as they are non destructive with respect to further propagation of plants. In the protocol developed by Son et al., (2011) and Shylaja et al., (2014) with flower bud explants also, high genotypic difference was observed for in vitro response.

In conclusion, through this investigation it has been possible to develop an highly efficient and reproducible in-vitro mass propagation protocol for commercial micropropagation of gerbera was thus developed with unopened flower buds as explant. Based on the results it may be concluded that the in-vitro mass propagation protocol developed in this investigation could profitably be explored for the commericial cultivation of gerbera. Genotypic differences were observed in all stages of in vitro propagation. The present protocol of propagation may help in obtaining adequate number of plantlets for cultivation in fulfilling the requirements of the local market of gerbera.

\section{References}

Altaf, N., Khan, A. R., Ali, L. and Bhatti, I. A., 2009, Tissue culture of Gerbera. Pakistan J. Botany. 41(1): 7-10.

Akter, N., Hoque, M. I. and Sarker, R. H., 2012, In vitro propagation in three varieties of Gerbera (Gerbera jamesonii Bolus.) from flower bud and flower stalk explants, Plant Tissue Cult. \& Biotech., 22(2): 143-152. 
Aswath, C. and Choudhary, M. L., 2001, Effect of cytokinin on the proliferation of multiple shoots in gerbera. Indian $J$. Hort., 58(4): 383-385.

Aswath, C. and Choudhary, M.L., 2002, Rapid plant regeneration $\mathrm{f}$ rom callus culture of Gerbera jamesonii. Acta Bot. Croat, 61(2): 125-134.

Aswath, C. and Choudhary, M. L., 2004, Regenration response of in vitro derived leaf explants of Gerbera jamesonii. $J$. Orn. Hort., 7(3-4): 276-282.

Aswath, C., Deepa, S.M. and Choudhary, M.L., 2003, Commercial multiplication of gerbera (Gerbera jamesonii Bolus) through in vitro shoot tip culture. $J$. Ornamental Hort., 6: 303-309.

Aswath, C. and Nazneen, S., 2004, An Improved method for in vitro propagation of gerbera. J. Orn. Hort., 7(2): 141-146.

Bailey, L.H., 1963, The standard cyclopaedia of horticulture. Vol IIF- O. Macmillan, New York. pp.1333.

Bhatia, R., Singh, K. P., and Singh, M. C., 2012, In vitro mass multiplication of gerbera (Gerbera jamesonii) using capitulum explants. Indian J. Agri. Sci., 82(9): 768-774.

Chen, X., Li, M. and Lin, X., 2006, In vitro propagation of Gerbera jamesonii. J. Fujian Agri. Forestry University Natyral Science Edition, 35(2): 169172.

Deepaja, S. M., 1999, Micropropagation of Gerbera (Gerbera jamesonii Bolus), M.Sc. Thesis, Univ. Agric. Sci., Bangalore (India).

Dole, J.M. and Welkins, H.F., 1999, Gerbera. In: Floriculture principles and species. Prentice Hall, Inc. New jersey, pp. 356360.

George, E. F. and Sherrington, P. D., 1984, Plant propagation by tissue culture. Handbook and directory of commercial laboratories. Exegetics 1td., Eversely, Baring Stoke, Hants, U.K.

Harel, D., Kuzmicic, I., Jug-Dujakovic, M. and Jelaska, S., 1993, The effect of genotype on gerbera shoot multiplication in vitro. Acta. Bot. Croatia, 52: 25-32.

Hempel, M., Petos, W. B. and Tymoszuk, J., 1985, The influence of cytokinins on multiplication and subsequent rooting of gerbera in vitro. Acta Hort., 167: 301305.

Jain, S.M., 2006, Mutation assisted breeding for improving ornamental plants. ISHS Acta Horticulturae, 714(1).

Kadu, A. R., 2013, In vitro micropropagation of gerbera using auxillary bud. Asian J. Biol. Sci. 8: 15-18.

Kanwar, J.K. and Kumar, S., 2008, In vitro propagation of Gerbera- A Review. Hort. Sci. (Prague), 35(1): 35-44.

Kumar, S., Kanwar, J. K. and Sharma, D. R., 2004. In Vitro regeneration of Gerbera Jamesonii Bolus from leaf and petiole explants. J. Plant Biochem. Biotech., 13(1): 73-75.

Kumar, S. and Kanwar, J. K., 2006, Regeneration ability of petiole, leaf and petal explants in gerbera cut flower cultures in vitro. Folia Horticulturae, 18: $57-64$.

Laliberte, S., Chretien, I. and Vieth, J., 1985, In vitro plantlet production from young Capitulum explants of Gerbera jamesonii. Hort. Sci., 20: 137-139.

Mandal, A. K. A. and Datta, S. K., 2002, Introduction of gerbera cultivation in Lucknow agro-climate through tissue culture of young flower head. Indian $J$. Biotech., 1(2): 212-214.

Mandal, A. B., Das, S. and Biswas, A., 2010, In vitro propagation of gerbera and assessment of clonal fidelity of the microclones. Indian J. Hort., 67: 357361. 
Modh, F. K., Dhaduk, B. K. and Shah, R. R., 2002, Factors affecting micropropgation of gerbera from capitulum explants. $J$. Orn. Hort., 5(1): 4-6.

Mohammed, S. A. and Ozzambak, M. E., 2007, In vitro formation of gerbera (Gerbera jamesonii Bolus) plantlets from capitulum explants. Propagation of Orn. Plants, 7(1): 37-42.

Murashige, T., Sepra, M. and Jones, J.B., 1974, Clonal multiplication of gerbera through tissue culture. Hort. Sci. 9: 175180.

Nhut, D. T., Nguyen, T.H., Nguyen, T. D., Silva, J. A. T. and Van, K. T. T., 2006, Latest applications of thin cell layer (TCL) culture systems in plant regeneration and morphogenesis. Floriculture Ornamental Plant Boitech., 465-471.

Nhut, D.T., Huong, N.T.D., Don, N.T., Hai, N.T., Nthien, N.Q. and Vu, N.H., 2007, Effect of genotype, explant size, position and culture medium on shoot generation of Gerbera jamesonii by receptacle transverse thin cell layer culture. Scientia Horticulturae, 111(24): 146-151.

Orlikowska, T., Nowak, E., Marasek, A. and Kucharska, D., 1999, Effects of growth regulators and incubation period on in vitro regeneration of adventitious shoots from gerbera petioles. Plant Cell Tiss. Org. Cult., 59: 95-102.

Panse, V. G. and Sukhatme, P. V., 1967, Statistical Methods for Agricultural Workers, ICAR. New Delhi.

Parthasarthy, V. A. and Nagaraju, V., 1999. In vitro propagation in Gerbera jamesonii Bolus. Ind. J. Hort.,56(1): 8285.

Prasanth, M. and Sekar, K., 2004, Studies on age of explant on callus induction in gerbera cv. Mammut. Scientia Horticulturae 9: 207-211.
Peper, H., Brandis, A.V. and Dopke, H., 1971, Clonal propagation of gerberas can be profitable. Result from Ahlem on the culture and clonal propagation of gerberas. Taspo, 105:7-11.

Pierik, R. L. M., Jansen, J. L. M., Maasdam, A. and Binnendijk, C. M., 1975, Optimization of gerbera plantlet production from excised capitulum explants. Scientia Horticulturae, 69(4): 351-357.

Pierik, R. L. M., Steegmans, H. H. M., Verhaegh, J. A. M. and Wouters, A. N., 1982, Effect of cytokinin and cultivar on shoot formation of Gerbera jamesonii in vitro. Netherlands J. Agri. Sci. 30: 341-346.

Ray, T., Saha, P. and Roy, S. C., 2005, In vitro plant regeneration from young capitulum explants of Gerbera jamesonii. Plant Cell Biotech. \& molecular Bio, 6(1\&2): 35-40.

Rahman, M., Ahmed, B., Islam, R., Mandal, A. and Hossain, M., 2014, A biotechnological approach for the production of red gerbera (Gerbera Jamesonii Bolus). Nova J. Medical and Biol. Sci., 2(1): 1-6.

Sachiva, T., 1975, Vegetative propagation in gerbera improvement. Annali dell Istituto Sperimentale per la Floricultura, 6: 133-135.

Schiva, T., Lercari, B. and Giusta, R., 1982, Micropropagation of Gerbera: variable response to in vitro culture. Annalidell'Istituto-Sperimentale-per-laFloricoltura, 13: 56-61.

Schum, A. and Busold, M., 1985, In vitro shoot production from inflorescences of Gerbera. Gartnerborse Gartenwelt, 85: 1744-1746.

Shylaja, M. R., Sashna, P., Chinjusha,V. and Nazeem, P.A., 2014, An efficient micropropagation protocol for Gerbera jamesonii Bolus from flower buds. Int J. 
Plant, Animal and Env. Sci. 4(3): 641643.

Son, N.V., Mokashi, A.N., Hegde, R.V., Patil, V.S. and Lingaraju, S., 2011, Response of gerbera (Gerbera jamesonii Bolus) varieties to micropropagation. Karnataka J. Agric. Sci. 24(3): 354-357.

Srivastava, R. and Sharma, G., 2005, Somatic embryogenesis in gerbera (Gerbera jamesonii Bolus ex Hooker f.) as influenced by explants. J. Orn. Hort., 8(2): 128-130.

Thakur, P. S., Ghorade, R. B. and Rathod, T. H., 2004, Microprogation studies in gerbera. Annals Plant Physi., 18(25.): 133-135.

Tyagi, P. and Kothari, S. S., 2004, Rapid in vitro regeneration of Gerbera jamesonii (H. Bolus ex. Hook F.) from different explants. Indian J. Biotech. 3: 584-586.
Wang, C. and Xiang, Y., 2001, Tissue culture and quick propagation of pot Gerbera jamesonii. J. Zhejiang Forestry Sci. Tech., 21(3): 30-31.

Warar, M. H., Kulkarni, B. S., Jagadeesha, R. C. and Reddy, B. S., 2008, Effect of cytokinins with auxin on proliferation of multiple shoots in gerbera (Gerbera jamesonii B.) var. Sciella. Karnataka J. Agri. Sci., 21(4): 597-599.

Winarto, B. and Yufdy, M. P., 2017, Establishment of in vitro propagation protocol of Gerbera jamesonii Bolus ex Hook F. explant and media selection to plantlet acclimatization. Agraarteadus J. Agric. Sci., 32-40.

Zheng, X., Wang, J. and Li, M., 2002. Factors affecting organogenesis in Gerbera jamesonii Bolus cultures in vitro. J. Jiangsu forestry Sci. Tech., 29(1): 2931.

\section{How to cite this article:}

Rashmi, R., C. Aswath, M.V. Dhananjaya, and Satish R. Patil 2018. Commercial Multiplication of Gerbera (Gerbera jamesonii Bolus ex. Hooker F.) from Young Capitulum Explants Int.J.Curr.Microbiol.App.Sci. 7(11): 2524-2537.

doi: https://doi.org/10.20546/ijcmas.2018.711.287 